\section{TREATMENT OF GUINEA-WORM.}

To the Editor, " Indian Medical Gazette."

SIR,-In your number for August, page 305, I notice a reference to what purports to be a " new treatment for guinea-worm," viz., the injection of perchloride of mercury ( 1 in 1.000).

It may be of interest to note that I employed precisely this method in the case of two sepoys in the No. 14 Field Hospital at Mandalay in 1887.

The plan was proposed to me by Surgeon-Major J. Forbes Keith, I.M.S., but whether it was an original suggestion or not on his part I do not know. The result of the treatment was the disappearance of the worms, and the return of the man to duty within a week.

W. B. BANNERMAN, M.D., SURGN.-CAPT., I.M.S. Madras, 18th October 1894.

\section{AN APPEAL.}

To the Editor, "Indian Medical Gazette."

SIR,-I have been asked by the Treasurer of the Royal Medical Benevolent College at Epsom to make an appeal to the profession in India for help.

The College provides pensions for 50 aged medical men or widows of medical men; and a school offering special advantages to the sons of medical men, fifty of whom are advantages to the sous, receiving board, clothing and a firstfund ex charge.

Special attention is paid to the teaching of natural science, and the College is recognised as a "School of Science" by the Committee of the Conjoint Board of the Royal Colleges the Committee of the Cons. Ten medical scholarships at of Physicians and Surgeons. the hospital schools in London, ranging in value from 90 to 125 guineas, and six scholare competed for annually, besides tenable in the school, are competaps varying from $£ 30$ to $£ 60$ several exhibitions and scholarships varying from

a year for candidates proceedir Joseph Fayrer is President,

The Council, of which Sir Joseph Fayrer is foundation requires $£ 6.000$ a year for investments is only about $£ 800$ scholars. The income from inves $£ 3,000$, of which the profesand regular subscriptions about $\$ 23,000$. The charity is the most sion contributes abodical societies in England and is most useful of all the medical societies in the deserving of help. Subscriptions may be sent to me or to the Honorary Treasurer, Dr. C. Halman, 6 , Gloucester Place, Portman Square, London, and $I$ man who may be willing the names of any registered medicies. From what $I$ know of to act as Honorary Local Secretaredical men in India Epsom the school I should think that to medages for the education of College gives very superior advantages for the education of their children.

DARJEELING,

15th October 1894 .

\section{ROBERT HARVEY} Surgeon-Colonel.

\section{EPIDEMIC OF YAWS IN ASSAM.}

To the Editor, "Indian Medical Gazette."

SI - I have just read the interesting account of the "Epidemic of Yaws" published byMr. Powell in yourissue for The doubt that the dise more September. Ihere than is generally supposed. I published common in India than is ge the South Indian Branch of a case in The Transactions of ther October last. This the British Medical Association the disease from a playpatient had apparently contracted suffering from an attack. mate who came from Pondicherias, and Surgeon-Lieuenant$I$ have seen another case in Madras, and Surgeon-LieuenantColonelEsmonde White showed me name of " Portuguese disease is known in Travancore byc treatment had no effect, ulcer." In my case local antiseptapidly when the patient but the disease disappeared of the external application became salivated as the of mercurial ointment.

MADRAS, 17 th October 1894 .

\section{J. MAITLAND, M.D.,} Surgn.-Major.

\section{CHOLERA AND BREAD.}

To The Editor, "Indian Medical Gazette."

At the late meeting of the British Medical AssociaSir,-At the late meetdo, and I read a joint paper in which
tion my friend, Dr. Waldo, we disputed the truth of the assumption that bread was sterilised in the baker's oven.

We showed that cultures of thirteen different species of micro-organisms were obtainable from the centre of newlybaked loaves taken at random from bake-houses in various parts of London, rich and poor. We concluded, therefore, that baking does not necessarily destroy the organisms (or their spores) that may be present in dough. It then occurred to us that if this observation were true of non-patho. genic bacteria, there was no particular reason why it should not also apply to the organisms of specific disease Experimenting in that direction, we found that it was possible to obtain cultures of the original bacillus from bread of which the dough had been mixed with a specific bacillus. In this way we procured cultures of " comma" bacillus from loaves made of dough that had been previously infected with a pure culture of that organism.

The latter part of our investigations, namely, that which deals with artificially infected bread, is still incomplete. Even at this stage, however, we think it advisable to make public a portion of the results.

In our paper we expressed an opinion that bread might be proved, at no distant date, to be an active agent in the spread of many epidemic diseases. It seems certain, at any rate, from the conditions of many of our English bakeries that the dough must be sometimes exposed to contamination by the specific organisms of enteric fever and of tubercle.

Cholera is fortunately no longer epidemic in Great Britain. From our point of view it is desirable that in some place where the disease is prevalent, a bacteriological investigation should be made on the spot to ascertain if bread may not actually contain the living germs of cholera and be the means of spreading the malady.

Our chain of reasoning is this. Dough is mixed with the ordinary drinking water of the district where it is made; cholera is essentially a water-borne disease; the microorganisms of dough are not all destroyed by baking; therefore, the living germs of cholera may be distributed to the consumers of bread in a cholera-infected district.

Obvious preventive measures are at hand in (1), Sterilisation of water employed in mixing the dough; (2), Sterilisation of bread by toasting it in thin slices.

This letter is written in the hope that some of your readers may be induced to make personal enquiries into this important subject, not less in the interests of progres. sive medical science than of suffering humanity.

Welbeck Street, London, W.,

DAVID WALSH.

$30 t h$ September 1894.

\section{Gypointments, deate, ate.}

\section{APPOINTMENTS.}

THE Commander-in-Chief in India is pleased to make the following appointment:-

BRow N, Brigade-Surgeon-Lieutenant-Colonel H. T., Army Medical Staff, to officiate as Principal Medical Officer, Peshawar District, vice Brigade-Surgeon-Lieutenant-Colonel G. McB. Davis, appointed Principal Medical Officer, Waziristan Delimitation Escort.

WooD, Surgeon-Captain H. S., from the medical charge of the Wing, 42nd Gurkha Rifles, to the officiating medical charge of the regiment, vice Surgeon-Lieutenant B. R. Chatterton.

Chatterton, Surgeon-Lieutenant B. R., from the officiating medical charge of the 42nd Gurkha Rifles, to the medical charge of the Wing, vice Surgeon-Captain H. S. Wood.

HARE, Surgeon-Captain E. C., whose services have been placed at the disposal of the Government of India, Home Department, is confirmed as Civil Surgeon of Chanda, with retrospective effect from the 24th June 1889 .

Medical Department.

FALL, Surgeon-Captain E. A. W., Officiating Civil Sur. ge $\mathrm{a}$ of Tippera, is appointed to act as Civil Surgeon of 